\title{
CES
}

COOPERATIVISMO E ECONOMÍA SOCIAL

Núm. 43 (2020-2021), páxs. 327-331

ISSN: $2660-6348$

\section{NOTAS PARA UM DEBATE ACERCA DA “EMPRESA SOCIAL"}

\author{
NOTES FOR A DEBATE ABOUT "SOCIAL ENTERPRISE”
}

\author{
EDUARDO GRAÇA*
}

Presidente da direção da Cooperativa António Sérgio para a Economia Social (CASES), eduardograca@ cases.pt. Endereço postal: Rua Américo Durão 12A, 1900-064 Lisboa. 

$\mathrm{S}$ aúdo em primeiro lugar a realização desta iniciativa ${ }^{1}$ trazendo ao debate $o$ tema da empresa social que abordo brevemente, no contexto da economia social, que a Lei n. ${ }^{\circ}$ 30/2013 de 8 de maio, Lei de Bases da Economia Social (LBES), consagra com esta designação na esteira da CRP que consagra o setor com a designação histórica de "setor cooperativo e social", praticamente coincidente, em todos os aspetos substanciais, com a designação adotada pela LBES.

Esta Lei enquadra, e sistematiza, no seu art. ${ }^{\circ} 4 .^{\circ}$, o que ocorreu pela primeira vez no ordenamento jurídico português contemporâneo, as entidades da economia social que integram a economia social.

Assim conforme a Lei integram a economia social as seguintes entidades, desde que abrangidas pelo ordenamento jurídico português:

a) As cooperativas;

b) As associações mutualistas;

c) As misericórdias;

d) As fundações;

e) As instituições particulares de solidariedade social não abrangidas pelas alineas anteriores;

f) As associações com fins altruísticos que atuem no âmbito cultural, recreativo, do desporto e do desenvolvimento local;

g) As entidades abrangidas pelos subsectores comunitário e autogestionário, integrados nos termos da Constituição no sector cooperativo e social;

h) Outras entidades dotadas de personalidade jurídica, que respeitem os princípios orientadores da economia social previstos no artigo $5 .^{\circ}$ da presente lei e constem da base de dados da economia social.

Este elenco adota um ordenamento das entidades integrantes da economia social que segue o que, livremente, designo por "conceito europeu" que inclui quatro grandes "famílias": cooperativas, mutualidades, associações e fundações. O legislador consagrou também, atenta a especificidade portuguesa, as Misericórdias, além das IPSS s, no caso destas, salvaguardando em alínea própria aquelas às quais o Estado não atribui automaticamente aquele estatuto, referidas em alíneas próprias, por razão da sua importância histórica, institucional e económica social. Abrange ainda "as entidades abrangidas pelos subsectores comunitário e autogestionário, integrados nos termos da Constituição no sector cooperativo e social".

A criação de uma alínea destinada a acolher "Outras entidades dotadas de personalidade jurídica que respeitem os princípios orientadores da economia

Colóquio Internacional do Projecto Times, Coimbra, 27 a 29 abril de 2021. 
social previstos no artigo $5 .^{\circ}$ da presente lei e constem da base de dados da economia social.", referidas na alínea h), justificou-se, a meu ver, pela necessidade de reconhecer a existência de entidades atípicas e/ou inovadoras, criadas por legislação anunciada no concerto das instâncias da UE, mas sem consagração no ordenamento jurídico português, tais como as "empresas sociais".

No entanto o entendimento acerca da abrangência e operacionalidade desta alínea tem sido alvo de entendimentos diversos que exemplifico com o do Prof. Rui Namorado enunciado num parecer que lhe solicitámos em 2016 e do qual tomo a liberdade de citar um excerto: ..."na vigência de uma Lei de Bases da Economia Social (LBES), o primeiro e irremovível critério, para determinar o âmbito da economia social, é o pleno respeito pelo que nessa lei se dispõe. E, uma vez que a pertença à economia social se baseia numa indicação taxativa do respetivo art. $^{\circ} 4^{\circ}$, não se suscitam problemas de interpretação que possam conduzir a posições diferenciadas.

É certo que a alínea h) do citado artigo abre um espaço excecional nessa taxatividade que fica por preencher. Mas fá-lo casuisticamente e não categorialmente; $e$, de qualquer modo, a questão levantada por essa alínea não tem que ser tida em conta, dado que ainda não estão preenchidos os pressupostos administrativos e organizacionais que lhe darão consistência prática."

Quero ainda deixar duas notas, que julgo pertinentes no contexto desta iniciativa, para melhor entendimento da génese do art. $^{\circ} 4 .^{\circ}$ da Lei de Bases da Economia Social:

O projeto de lei inicial, no que respeita ao elenco das entidades da economia social, ordenava-as de forma diversa em conformidade com a conceção que atribui ao designado "setor social" a primazia entre todas as entidades que integram a economia social, ou seja, acolhendo influência da "conceção americana" que afasta do perímetro das entidades da economia social as cooperativas e as mutualidades - embora naquele projeto sempre as incluísse embora não lhes dando a primazia no ordenamento das entidades consideradas;

O projeto de lei até à fase final de debate, em sede parlamentar, integrava um artigo no qual se consagrava a figura da "empresa social" que acabou por "cair", no momento imediatamente anterior à votação final, em favor da obtenção da unanimidade na aprovação da Lei, o que viria a verificar-se. Tal decisão ajuda a entender a inclusão e o teor da alínea h) deste artigo.

De forma sintética, inevitavelmente simplificada, a consagração de um conceito de empresa social no presente contexto português no seu encontro com a LBES, é uma questão em aberto, cuja discussão é ainda escassa e pouco densificada, quer no meio académico (de que esta iniciativa é exceção), quer pelas entidades da economia social, mas nem por isso de menor relevância pela crescente tendência para 
a hibridização de organizações com diversas naturezas jurídicas que assumem objetivos com forte vocação social.

O conceito de empresa social, que se aborda nesta oportuna iniciativa, está ainda em construção e depara-se com fortes reservas por parte do universo da economia social tal como delimitado pela LBES. Note-se, contudo, que há uma enorme diferença entre a criação de uma nova forma jurídica ou, em alternativa, de um estatuto jurídico, no qual determinadas entidades poderão ser incluídas, tendo em conta os princípios orientadores e os objetivos da sua atuação.

Há muito ainda que discutir neste particular, quer se aborde a questão da elaboração de um estatuto da empresa social ou, em alternativa, uma hipotética alteração à LBES, em qualquer dos casos no aprofundamento do debate que iluminará o caminho no qual se determine até onde a vontade do legislador queira abrir o perímetro conceptual da economia social. 